\title{
THE DEVELOPMENT OF AN ENTTEROCOCCAL PHAGE ASSAY FOR WATER SAMPLES
}

\author{
YF Ngeow ${ }^{\prime *}, C L$ Loh $^{2}$, CWWang $^{3}$ \\ Departments of Medical Microbiology' and Biochemistry,", University of Molaya, 50603 Kuala Lumpur, Malaysia
}

\begin{abstract}
Preliminary work was carried out for the development of a rapid method for the detection and enumeration of enterococcal phages in natural water. Eight calterococcal phages were isolated after amplification from water obtained from 2 local ponds. These were plaque-purified and used to test the phage susceptibility of 34 strains of enterococci isolated from pristine and polluted waters. Eight strains with the widest phage susceptibility were used as hosts in a double agar layer (DAL) and a single agar layer (SAL) assay for phage enumeration without pre-assay amplification. No phages were obtained with the DAL method with all 8 hosts. Using the SAL method, 2 phages were obtained with 1 of the 2 hosts used. Phage isolation was not improved by incubation at $44.5^{\circ} \mathrm{C}$. For rapid quantitative testing, the sensitivity of the assays has to be increased to enable phage isolation without the need for priot amplification.
(JUMMEC 1996 1(1):25-28)
\end{abstract}

KEY WORDS: Enterococci, phage, enumeration

\section{Introduction}

Standard tests for faecal contamination of water are based on the enumeration of coliform bacteria which are normally found in high concentrations in the faeces of all warm-blooded animals. However, it has been shown by a number of researchers that these bacteria may not be suitable indicators for assessing the hygienic quality of tropical waters as they have been found in significant numbers in water, soil and on epiphytic plants in tropical pristine environments $(1,2)$. Their replication in the natural environment has been postulated $(3,4)$ and if this were true, their presence in water would not necessarily indicate faecal contamination. In addition, faecal coliforms are less resistant to disinfection than some human pathogens like human enteric viruses which have been recovered from waters considered safe by faecal coliform tests(5),

In the search for better indicator organisms, Clostridium welchii, faecal streptococci and coliphages were found to be the most promising. $C$ welchil correlated better than faecal coliforms or faecal streptococci with wastewater contamination and behaved more like viruses in its resistance to chlorination and environmental factors(I). Coliphages appeared to be good indicators of longuterm enterovirus contamination of water even in the presence of chemical pollution(6). Faecal streptococci (>80\% Enterococcus faecalis) which are more numerous in the animal gut than in the human intestine, have been used mostly to obtain the faecal coliform
(FC):faecal streptococci (FS) ratio. In appropriate situations, a FC:FS ratio of $>4$ is strong evidence that contamination is by human waste whereas a ratio of $<0.7$ indicates pollution from livestock or poultry waste. Faecal streptococci have not been as extensively studied as faecal coliforms. They will not grow in water but their die-off rates in the environment are generally unknown although some species show remarkable tolerance to unfavourable conditions. Much less is known about the phages that lysogenize these streptococci and their distribution in the natural environment.

This paper describes some preliminary work on the detection and enumeration of faecal streptococcal ph. ages conducted with the aim of developing an assay for the study of the ecology of these phages and their potential use as an alternative indicator of faecal contamination of water. Since faecal streptococei are mostly enterococci, the latter terminology is used throughout this paper for simplicity.

\section{Materials and Methods}

\section{Isolation of enterococcal hosts}

Water samples collected from the Endau-Rompin watershed were filtered at the sampling point with bacte-

Corresponding author:

YF Ngeow

Department of Medical Microbiology. Facully of Medicine, University of Malaya, 50603 Kuala Lumpur, Malaysia 
riological field monitors (Millipore) and incubated up to 4 days at ambient temperatures on M-VFC holding medium before being transferred onto KF Streptococcus agar (Difco) for incubation at $44.5^{\circ} \mathrm{C}$. Water samples from Taman Jaya and the University of Malaya were transported back to the Department of Medical Microbiology in ice and examined within 4 hours of collection by membrane filtration using $0.45 \mathrm{~mm}$ membranes (Millipore) and KF Streptococcus medium for incubation. Typical enterococcal colonies on KF agar were identified by the API 20 STREP system (Bio Méreux, France).

\section{Isolation and enumeration of enterococcal phages}

Amplification of phages in water samples was carried out by adding $10 \mathrm{ml}$ of Enterococcus host to $10 \mathrm{ml}$ of concentrated $(10 \mathrm{x})$ basal broth and $90 \mathrm{ml}$ of water sample. The mixture was incubated overnight at $35^{\circ} \mathrm{C}$ with periodic shaking. At the end of incubation $0.1 \mathrm{ml}$ of the mixture was removed for titration.

Two phage assays were used, the American Public Health Association (APHA 919C) single agar layer (SAL) assay(7)and the DAL assay which was a modification of a double agar layer method for bacteriophage enumeration( 8$)$. The medium used for the SAL method consisted of trypticase soy broth to which was added per litre, calcium chloride dihydrate $(0.63 \mathrm{~g})$ sodium azide $(0.43 g)$ and agar $(15 g)$. The basal medium for the DAL assay was made up per litre with tryptose (10.0g), Lablemco ( $3.0 \mathrm{~g})$, sodium chloride $(5.0 \mathrm{~g})$, sodium azide $(0.2 \mathrm{~g})$ and calcium chloride dihydrate $(0.3 \mathrm{~g})$. Agar plates were prepared from this basal broth with $1.5 \%$ agar, while the soft agar overlay was prepared with $0.8 \%$ agar.

In both assays, a log phase culture of Enterococcus host was prepared by diluting an overnight culture 100-fold in fresh basal broth and incubating at $35^{\circ} \mathrm{C}$ for 5 hours. In the DAL assay, $3 \mathrm{ml}$ of the overlay assay medium were melted and allowed to cool to $50^{\circ} \mathrm{C}$. To this was added $1 \mathrm{ml}$ of water sample, $1 \mathrm{ml}$ of the host suspension and $0.1 \mathrm{ml}$ of a $0.4 \%$ triphenyltetrazolium chloride (TPTZ) solution in ethanol. The mixture was then poured over the prepared agar plates, allowed to set and incubated at $35^{\circ} \mathrm{C}$.

In the SAL assay, $5 \mathrm{~m}$ l of water sample, $1 \mathrm{ml}$ of host suspension and $0.1 \mathrm{ml}$ of the $0.4 \%$ TPTZ solution were added to the basal medium. After overnight incubation, phage plaques were counted.

\section{Phage susceptibility of enterococcal hosts}

Phages were isolated from plaques and grown up in flasks with host suspensions at log phase for 24 hours. Bacterial cells and debri were then removed by centrifugation and the phage preparation treated with chloroform to kill remaining bacteria. The phages were used to screen Enterococcus phage susceptibility by swabbing concentrated phage preparations $\left(10^{5}\right.$ to $\left.10^{7}\right)$ onto agar plates and then streaking Enterococcus strains across the swabbed area. After incubation, an area of no growth was evident in the streaks with strains that were susceptible to the phage on the agar plate.

\section{Results}

Thirty-four strains of enterococci were isolated from the environment. Twenty-four were from pristine waters within an equatorial rain forest watershed (EndauRompin, Pahang), 7 from 3 sites within the same watershed that received light human faecal contamination, 2 from sewage-contaminated Taman Jaya recreational lake in Petaling Jaya and I from a sewage pond in Ottawa, Canada. These included $22 \mathrm{E}$ faecolis, $4 \mathrm{~S}$ bovis, $2 \mathrm{E}$ ovium, $3 \mathrm{E}$ faecium and 3 which were not identified to species level.

Initially, 7 of these 34 strains of enterococci were randomly selected as preliminary hosts to test water samples obtained from the Taman Jaya recreational lake and the University of Malaya pond. Phage amplification and detection was successful with 3 of the preliminary hosts (C10-10, F100-7, $\mathrm{H}(00-8)$ and a total of 8 phages were isolated and plaque purified $(4 \mathrm{~A}, 4 \mathrm{~B}, 5 \mathrm{~A}, 5 \mathrm{~B}$, $6 \mathrm{~A}, 6 \mathrm{~B}, 6 \mathrm{C}, 6 \mathrm{D})$.
75.8

These 8 phages were then used to screen all the 34 Enteracaccus isolates to determine their phage susceptibility pattern (Table 1). Only I Enterococcus isolate (an E. foecolis) was not susceptible to any of the 8 panel phages. The majority (70\%) were susceptible to 2.4 of the phages. All 8 phages caused lytic infection in more than I strain of Enterococcus and each exhibited a different host range which was cross-species except for $p$ hages $4 A$ and $4 B$ which appeared to be species-specific as they caused lytic infection only in $E$. faecalis.

Eight strains with the widest susceptibility to the panel of phages used were chosen as candidate hosts for subsequent phage assays (Table 2). Seven ( all from EndauRompin) were selected based on their susceptibility to over $50 \%$ of the panel phages. The eighth (PJ-2) was 
included for comparison as the only non-Endau-Rompin isolate.

All 8 candidate hosts were first used in the DAL assay without pre-assay amplification, on water samples collected from the Taman Jaya lake and University of Malaya pond. No phages were isolated. The samples were then tested with the SAL assay using 110-2 and $H_{1 / 00-8}$ as hosts. Two plaques were obtained with host] $10-2$ at $35^{\circ} \mathrm{C}$ incubation. In the SAL assay, 2 variations in incubation temperature were tried out:a) incubation at room temperature and b) an initial incubation at $35^{\circ} \mathrm{C}$ for 3 hours followed by overnight incubation at $44.5^{\circ} \mathrm{C}$. In both cases, no advantage was obtained over incubation at $35^{\circ} \mathrm{C}$. Besides, the Enterococcus host grew very poorly at the lower and higher temperatures, making the culture plates difficult to read.

To compare the phage assays with the standard (APHA) faecal coliform, enterococci and coliph. age enumeration tests, all 4 examina. tions were carried out on 3 water samples : a) water from Taman Jaya lake

\begin{tabular}{|c|c|c|}
\hline Water source & Test method & $\begin{array}{l}\text { No. of organisms } \\
\text { (CFU/100ml or } \\
\text { PFU/100ml) }\end{array}$ \\
\hline Taman Jaya lake & $\begin{array}{c}\text { Enterococcus phage SAL } \\
\text { Enterococcus phage DAL } \\
\text { Coliphage } \\
\text { E coli MF } \\
\text { Enterococcus MF }\end{array}$ & $\begin{array}{c}<5 \\
<25 \\
O G \\
1.1 \times 10^{5} \\
4.0 \times 10^{4}\end{array}$ \\
\hline University Malaya pond & $\begin{array}{c}\text { Enterococcus phage SAL } \\
\text { Enterococcus phage DAL } \\
\text { Coliphage } \\
\text { E. coll MF } \\
\text { Enterococcus MF }\end{array}$ & $\begin{array}{c}<5 \\
<25 \\
530 \\
1.1 \times 10^{4} \\
1.2 \times 10^{4}\end{array}$ \\
\hline Animal faecal washing & $\begin{array}{c}\text { Enterococcus phage SAL } \\
\text { Enterococcus phage DAL } \\
\text { Coliphage } \\
\text { E. coli MF } \\
\text { Enterococcus MF } \\
\end{array}$ & $\begin{array}{c}<5 \\
<25 \\
>2.0 \times 10^{4} \\
3.0 \times 10^{6} \\
2.7 \times 10^{7} \\
\end{array}$ \\
\hline
\end{tabular}
b) water from the University of Malaya pond and c) faecal washing from the Faculty of Medicine's animal house. No enterococcal phages were detected in any of the samples although high counts were obtained for coliphages, E. coli and enterococci (Table 3).

\section{Discussion}

Researchers at the Faculty of Medicine, University of Malaya have shown significant correlation between membrane-faecal coliform counts and coliphage numbers in well waters located in Central Malaysia. Since enterococci have been often used as an alternative or adjunct indicator to coliform bacteria for faecal con. tamination of water, it was of interest to see if entero. coccal phages can also play a role in the assessment of water quality.
The first requirement for a phage assay was getting a suitable host organism like $E$. coli $C$ in the coliphage test. In the absence of reference strains for the assay of enterococcal phages, an attempt was made to identify suitable hosts from among the wild-type strains isolated from the environment. The 8 candidate hosts used in this study wert susceptible to at least 4 of the 8 phages isolated from 2 local ponds. For further development of the phage assay, more enterococcal strains need to be examined to select a host with the widest possible phage susceptibility, suitable growth characteristics and genetic stability for reliable phage infection.

With a phage amplification step, 8 phages were isolated with 3 preliminary hosts without much difficulty but in subsequent assays carried out without amplification, only 2 phages were isolated from a total of 23 attempts using water from the same ponds. In particular, the failure to detect enterococcal phages in samples with high counts of $E$. coli, enterococci and coliphage was disappointing. In a study on 1,145 well water samples in various locations in Malaysia(9), it was observed that coliphage counts were usually about 2 logs lower than coliform counts. This bacteria: phage ratio was also seen with coliforms and coliphages in this study but not with enterococci and enterococcal phages. Both the SAL and DAl methods are standard tests for bacteriophage enumeration and they worked well with the coliphages. The lower rate of enterococcal phage isolation in this study could be due to the use of unoptimised hosts or to the presence of much smaller numbers of enterococcal phages in the water samples studied. At their present stage of development, both the tests used are not yet totally satisfactory for the assay of enterococcal phages.

The SAL method appeared to be more sensitive than the DAL method probably because the inoculum used for the former $(5 \mathrm{ml})$ was larger than that for the latter 
(I $\mathrm{m}$ ). Using 4 replicates per assay, the limit of detection for the SAL assay was 5 PFU/100ml whereas that for the DAL assay was 25 PFU/100ml. This greater sensitivity with a simpler test should be advantageous for field work. Another modification which would facilitate field testing is room temperature incubation which would eliminate the need for a field incubator. On the other hand, incubation at $44.5^{\circ} \mathrm{C}$ would help to cut down on the background growth of contaminating bacteria. Unfortunately, both temperatures did not allow adequate growth of the host organism. Perhaps the culture medium could be improved to overcome this problem.

The US Environmental Protection Agency (US EPA, 1986) recommends that recreational waters should not have $>126 \mathrm{E}$ colil $100 \mathrm{ml}$ and $>33$ enterococci $/ 100 \mathrm{ml}$ for fresh water. By these standards, the 2 ponds surveyed should be considered hygienically unsafe for recreational use. Since the ponds have not been known to be health hazards, could the US EPA's requirements be too stringent for local waters? Is it possible that the high counts obtained for the 2 indicator bacteria be reflective of their multiplication in the water rather than faecal contamination? The findings in this preliminary study have identified directions for further research on the extra-intestinal survival and replication of bacterial and viral indirators of faecal contamination of water and the suitability of traditional standards of water quality for local recreational waters.

\section{Acknowledgement}

This research forms part of the Coliphage Field Kit Development Project at the University of Malaya which was funded by the IDRC, Canada.

\section{References}

1. Fujioka, RS, Shizumura LK. Clostridium perfringens, a refiable indicator of stream water quality.J Water Polut Control Fed 1985; 57: 986-992.

2 Rivera SC, Mazen TC and Toranzos GA. Isolation of fecal coliforms from pristine sites in a tropical rain forest. Appl Environ Microbiol 1988; 54:513-517.

3. Carillo $M$, Estrada $E$ and Hazen TC. Survival and enumeration of faecal indicators Bifidobocterium odolescentis and Escherichio coli in a tropical rain forest watershed. Appl Environ Microbiol 1985; 50:468-476.

4. Hardina CM, Fujioka RS. Soil: The environmental source of Escherichio coli and enterococci in Hawail's streams. Envirommental toxicology and water quality. 1991; 6:185. 195.

5. Berg G, Metcalf TG. Indicators of viruses in waters. In: Berg G,Ed. Indicators of viruses in water and food. Ann Arbor Science Pub Inc Michigan. 1978; 267-296.

6. El-Abagy MM, Dutka Bj and Kamel M. Incidence of coliphage in potable water supplies. Appl Environ Microbial 1988; 54: 1632-1633.

7. American Public Health Association, American Water Works Association and Water Pollution Control Federation. Standard Methods for Examination of Water and Wastewater (16th Edition). Washington D.C. 1985.

8. Adams MH. Bacteriophages, Interscience Publishers, New York. 1959.

9. Wang CW, Ngeow YF, Loh CL, Ho YC. Final Report. Water Quality Control (Southeast Asia) IDRC Centre File: (3-P-83-03.17-02-51) University of Malaya, 1989. 